\title{
IMPLEMENTASI TEKNIK HYPNOTEACHING DALAM PROSES PEMBELAJARAN PADA ANAK USIA DINI
}

\author{
Masdudi \\ IAIN Syekh Nurjati Cirebon \\ Email: masdudi.bandung@gmail.com
}

Article received: 14 Agustus 2018, Review process: 20 Agustus 2018

Article published: 30 September 2018

\begin{abstract}
Hypnoteaching is the art of communicating by giving suggestions so that students become smarter. with the suggestion given, it is expected that they will be aware and enlightened that there is tremendous potential that they have never optimized in learning. Hypnoteaching is a combination of the concept of teaching and learning activities with the science of hypnosis ...in hypnoteaching, the teacher acts as a hypnosis while students as suyet (people who are hypnotized), the teacher as hypnosis does not need to sleep his students when giving suggestions. teachers in the practice of hypnoteaching simply use persuasive language as a communication tool that can suggest students effectively. Use communication language that is in line with student expectations. Early Childhood Education (PAUD) is the age that holds the foundation for the growth and development of physical and spiritual education. In the learning process requires special treatment and the right techniques so that the learning process is successful. Hypnoteaching techniques are one of the right approaches given to early childhood. Because the benefits will provide psychological relaxation. learning will feel more fun, peaceful, calm, relaxed, and rich in suggestive meaning in learning in the classroom without having to reduce the essence of the curriculum objectives.
\end{abstract}

\section{Keywords: Hypnoteaching, Learning, Early Childhood}

\begin{abstract}
Abstrak
Hypnoteaching adalah seni berkomunikasi dengan jalan memberikan sugesti agar para siswa menjadi lebih cerdas. Dengan sugesti yang diberikan, diharapkan mereka tersadar dan tercerahkan bahwa ada potensi luar biasa yang selama ini belum pernah mereka optimalkan dalam pembelajaran. Hypnoteaching merupakan perpaduan dari konsep aktivitas belajar mengajar dengan ilmu hipnosis.. Dalam hypnoteaching, guru berperan sebagai hipnosis sementara siswa selaku suyet (orang yang dihipnosis), guru selaku hipnosis tidak perlu menidurkan anak didiknya ketika memberi sugesti. Guru dalam praktek hypnoteaching cukup menggunakan bahasa persuasif sebagai alat komunikasi yang dapat mensugesti siswa secara efektif. Gunakanlah bahasa komunikasi yang sesuai dengan harapan siswa. Pendidikan Anak Usia Dini (PAUD) adalah usia yang memegang pondasi bagi pertumbuhan dan perkembangan pendidikan jasmani dan rohaninya. Dalam proses pembelajarannya memerlukan perlakuan yang khusus dan teknik yang tepat agar proses pembelajarannya berhasil. Teknik hipnoteaching merupakan salah satu pendekatan yang tepat diberikan kepada anak usia dini. Karena manfaatnya akan memberikan relaksasi secara psikologis. Belajar akan terasa lebih menyenangkan, damai, tenang, rileks, dan kaya akan makna sugestif dalam pembelajaran di kelas tanpa harus mengurangi hakekat dari tujuan kurikulum.
\end{abstract}

Kata Kunci: Hypnoteaching, Pembelajaran, Anak Usia Dini 


\section{PENDAHULUAN}

Keberhasilan pendidikan banyak terkait dengan kualitas dan kompetensi gurunya. Seiring dengan menggeliatnya kesejahteraan guru, guru pun harus mengimbanginya dengan terus menata diri dan meningkatkan kualitas kompetensinya. Tanggung jawab dalam mengembangkan profesi pada dasarnya ialah meningkatkan tugas dan tanggung jawab profesinya. Guru harus sadar bahwa tugas dan tanggung jawabnya tidak bisa digantikan oleh orang lain, kecuali oleh dirinya. Demikian pula ia harus sadar bahwa dalam melaksanakan tugasnya selalu dituntut untuk bersungguh-sungguh dan bukan pekerjaan sambilan. Oleh karena itu guru dituntut agar selalu meningkatkan pengetahuan, ketrampilan, dan kemampuan dalam rangka pelaksanaan tugas profesinya. Ia harus peka terhadap perubahanperubahan yang terjadi khususnya dalam bidang pendidikan dan pembelajaran. Dunia ilmu pengetahuan tak pernah berhenti tapi selalu muncul hal-hal yang baru. Guru harus mengikuti perkembangan tersebut, sehingga ia harus lebih dahulu mengetahuinya daripada para siswa dan masyarakat pada umumnya. Disinilah letaknya pengembangan profesi dan tanggung jawabnya sebagai guru.

Guru berperan sebagai motor penggerak dan model di lingkungan sekolah maupun masyarakatnya seharusnya memiliki kompetensi dan kreativitas yang tinggi dalam melaksanakan proses pembelajaran terutama saat menemukan masalah dalam pembelajaranya. Kreativitas guru diartikan kemampuan seorang guru untuk membelajarkan siswanya dengan kemampuan yang diiringi sikap kreatif dan keingintahuan yang tinggi, keberanian mengambil resiko, tertantang oleh kemajemukan, imajinatif, serta menghasilkan produk yang kreatif dalam pembelajaran.

Salah satu tugas guru yang berat dan memerlukan kreativitas yang tinggi adalah guru yang mengajar di Raudathul Athfal (RA) atau PAUD. Mengajar siswa di bawah usia lima tahun itu sangat sulit. Banyak guru yang merasa kerepotan. Bagaimana tidak sulit, mereka dihadapkan pada siswa yang usianya masih dalam masa bermain. Kalaupun bisa mengajar, itu hanya bertahan beberapa saat setelah mereka bersusah payah untuk mendiamkan siswa yang bermain-main di dalam kelas. Pada akhirnya, siswa akan kembali bermain-main di tengah proses pembelajaran. Kondisi seperti ini sudah umum terjadi dan tidak dapat dihindarkan, karena memang faktor usia siswa yang masih dalam rangka bermain. Berat 
memang mengajar siswa di masa ini, tetapi itulah tugas yang harus dijalankan bagi para guru yang mengajar di sekolah PAUD dan RA/TK.

Salah satu target peningkatan kualitas pendidikan adalah tercapainya tujuan pendidikan. Untuk mencapai tujuan tersebut perlu adanya terobosan-terobosan inovatif dari para guru, yaitu mencari strategi baru atau penyempurnakan strategi yang sudah ada. Strategi ini meliputi: pendekatan, model, metode, dan teknik yang mampu menggiring siswa menjadi yang diharapkan oleh mayarakat, yaitu siswa yang cerdas, berperilaku baik, patuh pada guru dan orang tua, serta berprestasi.

Kreativitas guru sangat dibutuhkan dalam proses pembelajaran. Oleh karena itu seorang guru harus benar-benar dituntut untuk kreatif inovatif dalam mengajar sehingga tidak menimbulkan kebosanan dalam pembelajaran, karena pelajaran begitu sangat penting bagi kehidupan manusia.

Dalam pendidikan memang selalu ada hal yang menarik untuk dipelajari dan dikembangkan. Hal ini dikarenakan pendidikan memegang kunci utama dalam penentuan tinggi rendahnya mutu sumber daya manusia. Lagi pula, selalu ada perkembangan berarti dalam pendidikan, baik dari segi kurikulum, metode, dan media. Melalui pendidikan pula berbagai aspek kehidupan dikembangkan melalui proses belajar dan pembelajaran. Berbagai masalah dalam proses belajar perlu diselaraskan dan distabilkan agar kondisi belajar tercipta sesuai dengan tujuan yang ingin dicapai. Demi mencapai tujuan tersebut, banyak para ahli yang meneliti tentang bagaimana untuk meningkatkan mutu pendidikan.

Oleh karenanya, segala aspek dalam belajar dan mengajar selalu diperbaiki. Tidak halnya dalam bimbingan konseling, demi meningkatkan personalitas siswa, para ahli pun tak lepas mencari sesuatu yang dapat diperbaiki. Mulai dari pendekatan hingga permasalahan siswa tak lepas untuk diperhatikan. Karena semakin kompleksnya permasalahan siswa, bahkan tak hanya dari siswa sekolah menengah, saat ini para ahli mulai memperhatikan tentang kompleksnya permasalahan anak-anak SD bahkan AUD. Dengan berasumsi bahwa usia dini sangat penting karena menjadi pondasi bagaimana anak ketika besar nantinya. Oleh karena itu, agar layanan bimbingan dan konseling dapat tersalurkan pada anak usia dini, maka perlu adanya cara atau pendekatan maupun teknik yang digunakan. Untuk itu, penulis 
mencoba memaparkan pendekatan dan teknik apa saja yang ada dalam bimbingan dan konseling anak usia dini.

Sudah banyak solusi yang ditawarkan ke arah itu. Namun di sini penulis menawarkan sebuah solusi lain yaitu pendekatan hypnoteaching dalam pembelajaran pada anak usia dini. Hipnoteaching hadir memberi warna baru dalam kegiatan pembelajaran di dalam kelas. Di kalangan dunia pendidikan pendekatan ini belum resmi dan populer dipakai atau diakui sebagai sebuah pendekatan, namun sebenarnya pendekatan ini sudah sering diaplikasikan oleh para pendidik atau guru yang menguasai teknik hipnosis, karena pendekatan ini mencoba menggunakan praktek hipnosis dalam pembelajaran dan untuk kepentingan pembelajaran (Muhammad Noer, 2010:117).

Hypnoteaching adalah sebuah metode pembelajaran dengan menggunakan teknikteknik yang berlaku dalam hipnotis. Ini artinya guru yang mempraktekan hipnoteaching sama seperti para pelaku hipnotis yang menghipnotis subjek dengan tujuan-tujuan yang mengarah pada pencapaian tujuan belajar, (Hana Pertiwi, 2014:10).

Dalam memahami hipnosis terkadang masyarakat masih keliru dan salah paham termasuk masyarakat pendidikan. Hal ini terjadi karena mereka belum mengetahuinya, karena semua itu berawal dari sebuah pemahaman terhadap suatu ilmu. Padahal kalau seandainya semua orang tahu apa itu hipnosis dan berbagai macam manfaatnya khususnya dalam pembelajaran, maka hasilnya sungguh luar biasa.

MD. Isma Almatin (2010:3) menjelaskan, mengajar merupakan proses memasukan informasi ke dalam fikiran, informasi diolah di pikiran sadar. Informasi tersebut sudah sesuai kebutuhan ataukah bertolak belakang dengan program yang sudah ada. Apabila informasi tersebut sesuai maka akan dilanjutkan ke proses selanjutnya, yaitu masuk ke dalam pikiran bawah sadar. Di pikiran bawah sadar inilah informasi akan disimpan untuk kemudian difungsikan sesuai kebutuhan. Hypnoteaching merupakan suatu teknik yang efektif dan efesien untuk menghantarkan informasi ke dalam pikiran bawah sadar.

Dalam hypnoteaching, guru berperan sebagai hipnosis sementara siswa selaku suyet (orang yang dihipnosis), guru selaku hipnosis (orang yang menghipnosis) tidak perlu menidurkan anak didiknya ketika memberi sugesti. Guru dalam praktek hypnoteaching cukup menggunakan bahasa persuasif sebagai alat komunikasi yang dapat mensugesti 
siswa secara efektif. Gunakanlah bahasa komunikasi yang sesuai dengan harapan siswa.

Dalam arti turunkan gelombang otak siswa dari beta menjadi alpha atau tetha.

Gunakan bahasa yang dimengerti oleh siswa. Sebab, sangat tidak mungkin hipnosis bekerja secara efektif sementara suyet tidak mengerti bahasa yang digunakan hipnosis. Cukuplah bagi guru untuk mengkondisikan dan menguasai kelas. Arahkan perhatian serta konsentrasi siswa pada satu fokus titik, yakni pada bahasa komunikasi sugestif sang guru. Jika kondisi kelas dan prilaku siswa dapat dikuasai dengan baik, maka siswa bisa menuruti apa saja arahan guru. Ketika siswa siap menerima sugesti positif konstruktif yang dikehendaki. Masukan nilai-nilai, keyakinan, mentalitas, dan kebiasaankebiasaan positif yang harus dilakukan oleh siswa dalam kehidupanya.

Pelaksanaan hypnoteaching tidak cukup hanya dilakukan sekali atau dua kali saja, tetapi sebaliknya dilakukan secara berulang kali dengan jalan merepetisi atau mengulangi kalimat-kalimat sugesti untuk mempercepat masuk ke dalam pikiran bawah sadar siswa.

Berdasarkan uraian tentang latar belakang dan problematika sebagaimana dikemukakan di atas sebagai indikator penelitian ini diharapkan dapat muncul jawaban terhadap pertanyaan, sebagai berikut:

a. Bagaimanakah implementasi teknik hypnoteaching dalam proses pembelajaran pada anak usia dini di RA?

b. Hambatan apa saja yang mempengaruhi pelaksanaan teknik hypnoteaching dalam proses pembelajaran di RA?

c. Seberapa jauh dampak keberhasilan implementasi teknik hypnoteaching dalam proses pembelajaran di RA?

\section{RELEVANSI TEORI}

Dalam keseluruhan proses pendidikan di sekolah, pembelajaran merupakan aktivitas yang paling utama. Ini berarti bahwa keberhasilan pencapaian tujuan pendidikan banyak tergantung dari bagaimana proses pembelajaran berlangsung, semakin pembelajaran efektif, maka semakin besar tercapainya tujuan dari pembelajaran tersebut.

Pembelajaran menurut Mohamad Surya (2004: 7), yaitu suatu proses yang dilakukan individu untuk memperoleh suatu perubahan perilaku yang baru secara keseluruhan, sebagai hasil dari pengalaman individu itu sendiri dalam interaksi dengan lingkunganya. 
Pembelajaran dikatakan berhasil apabila siswa sebagai subyek yang belajar mampu mengembangkan potensinya melalui belajar itu sendiri, dan tujuan yang telah ditetapkan tercapai secara efektif (Nana Sudjana, 2002: 35). Pembelajaran dapat didefinisikan sebagai suatu proses yang mana suatu kegiatan berasal atau berubah lewat reaksi dari suatu situasi yang dihadapi, dengan keadaan bahwa karakteristik-karakteristik dari perubahan aktivitas tersebut tidak dapat dijelaskan dengan kecendrungan-kecendrungan reaksi asli, kematangan, atau perubahan-perubahan sementara dari organisme (Sogiyanto,2006: 15).

Definisi di atas dapat dipahami bahwa pembelajaran terjadi ketika seseorang berubah karena suatu kejadian dan perubahan yang terjadi bukan karena perubahan secara alami atau karena menjadi dewasa yang dapat terjadi dengan sendirinya atau karena perubahanya sementara saja, tetapi lebih karena reaksi dari situasi yang dihadapi yaitu belajar.

Dalam aktivitas kehidupan manusia sehari-hari hampir tidak pernah dapat terlepas dari kegiatan belajar, baik ketika seseorang melaksanakan aktivitas sendiri, maupun di dalam suatu kelompok tertentu. Dipahami ataupun tidak dipahami, sesungguhnya sebagian besar aktivitas di dalam kehidupan sehari-hari merupakan kegiatan belajar. Dengan demikian dapat dikatakan, tidak ada ruang dan waktu dimana manusia dapat melepaskan dirinya dari kegiatan belajar, dan itu berarti pula bahwa belajar tidak pernah dibatasi usia, tempat, maupun waktu, karena perubahan yang menuntut terjadinya aktivitas belajar.

Hypnoteaching adalah salah satu pengembangan metode pembelajaran terbaru. Meskipun di Indonesia belum banyak yang menggunakan, tetapi hypnoteaching telah terbukti efektif dalam mengoptimalkan kegiatan belajar mengajar di sekolah. Dengan munculnya metode hypnoteaching, diharapkan masalah-masalah siswa yang terkait dengan pembelajaran di sekolah mampu dipecahkan. Secara tidak langsung, hal tersebut menuntut guru disekolah bisa menguasai hypnoteaching, karena hanya bisa dilakukan oleh seorang guru di sekolah.

Menurut Heriyanto Nurcahyo (Ibnu Hajar, 2011: 75), secara harfiah, hypnoteaching berasal dari kata hypnosis dan teaching. Dari sini, kemudian bisa diartikan bahwa hypnoteaching adalah seni berkomunikasi dengan jalan memberikan sugesti agar para siswa menjadi lebih cerdas. Dengan sugesti yang diberikan, diharapkan mereka tersadar dan 
tercerahkan bahwa ada potensi luar biasa yang selama ini belum pernah mereka optimalkan dalam pembelajaran.

Muhammad Noer (2010: 118), mengartikan hypnoteaching sebagai proses pengajaran yang dapat memberikan sugesti kepada para siswa. Adapun makna tidur dalam pembelajaran hypnoteaching berarti menidurkan sejenak pikiran sadar dan mengaktifkan pikiran bawah sadar.

Hypnoteaching menekankan pada komunikasi alam bawah sadar siswa, baik yang dilakukan dalam kelas maupun luar kelas. Hal ini bisa dilakukan dengan berbagai cara, seperti afirmasi, sugesti, dan imajinasi. Afirmasi dan sugesti memiliki kekuatan luar biasa. Kemampuan afirmasi dan sugesti yang terus terngiang dalam otak, mampu mengantarkan seseorang pada apa yang dipikirkan. Sedangkan imajinasi merupakan proses membayangkan sesuatu terlebih dahulu, baru melakukannya. Dalam hal ini guru harus mampu membiarkan siswa berekspresi dan berimajinasi.

Hypnoteaching merupakan perpaduan dari konsep aktivitas belajar mengajar dengan ilmu hipnosis. Belajar akan terasa lebih menyenangkan, damai, tenang, rileks, dan kaya akan makna sugestif dalam pembelajaran di kelas tanpa harus mengurangi hakekat dari tujuan kurikulum. Dalam pembelajaran hypnoteaching siswa berada pada gelombang otak alpha atau theta yang memudahkan siswa menyerap pelajarannya dan masuk dalam memory jangka panjang, sehingga siswa tidak akan pernah lupa terhadap apa yang diajarkan.

Hipnosis berasal dari kata hypnos yang berarti tidur. Namun hipnosis itu sendiri bukanlah tidur. Secara sederhana, hipnosis adalah fenomena yang mirip tidur, dimana alam bawah sadar lebih mengambil peranan, dan peran alam sadar berkurang. Pada kondisi semacam ini, seseorang menjadi sangat sugestif (mudah dipengaruhi) karena alam bawah sadar, yang seharusnya menjadi filter logik, sudah tidak lagi mengambil peranan (Muhammad Noer, 2010: 17).

Menurut Hisyam A. Fahri (2008: 10), hipnosis adalah suatu kondisi pikiran saat fungsi analis logis pada pikiran direduksi sehingga memungkinkan individu masuk ke dalam kondisi bawah sadar (subconscious atau unconscious). Dalam keadaan itu tersimpan beragam potensi internal yang dapat dimanfaatkan untuk lebih meningkatkan kualitas hidup. Dengan kata lain, kondisi hipnos adalah kondisi di mana fungsi pikiran sadar yang 
bersifat cerdas, kritis, logis, dan analitis diendapkan, alias tidak difungsikan. Sementara itu, kinerja pikiran bawah sadar yang lugu, polos, jujur dan terkesan bodoh, difungsikan.

Menurut Milton H. Erickson dalam Nugroho (2008:7), hipnosis adalah suatu metode berkomunikasi, baik verbal maupun non verbal, yang persuasif dan sugestif kepada seorang klien sehingga dia menjadi kreatif (berimajinasi dengan emosional dan terbuka wawasan internalnya), kemudian bereaksi (baik persetujuan ataupun penolakan) sesuai dengan sistem nilai dasar spiritual yang dimiliki. Hipnosis merupakan permainan imajinasi otak manusia melalui teknik komunikasi persuasif dan sugestif.

Jika merujuk pada Kamus Besar Bahasa Indonesia (2008: 501), hipnosis adalah keadaan seperti tidur karena sugesti, yang pada taraf permulaan orang itu berada di bawah pengaruh orang yang membawakan sugestinya, tetapi pada taraf berikutnya menjadi tidak sadar sama sekali.

Sebagian orang sering membedakan kosakata "hipnosis" dan "hipnotis". Praktisi menganggap bahwa kosakata tersebut, pada prinsipnya, berkesesuaian makna karena dianggap sama-sama diterjemahkan dari kosakata bahasa Inggris "hypnosis". Namun, sebagian lagi menolak penggunaan kata "hipnotis" dijadikan sebagai padanan kata dari "hipnosis". Pendapat ini menganggap kosakata "hipnotis" tersebut diadaptasi dari bahasa Inggris "hypnotist" yang berarti pelaku kegiatan hipnosis. Hal ini dianggap sama dengan penerjemahan kata "hypnotherapy" menjadi "hipnoterapi" serta "hypnothe rapist" menjadi "hipnoterapis" (Willy Wong dan Andri Hakim, 2010: 1).

Melalui berbagai riset, ditemukan adanya perubahan gelombang otak saat kondisi hipnosis (trans) mulai dicapai. Perubahan gelombang otak tersebut dapat diukur dengan alat pengukur yang disebut elektroencepalograph (EEG). Secara garis besar, gelombang otak manusia dibedakan dalam empat jenis, yaitu beta, alpha, theta, dan delta (Ibnu Hajar, 2011: 49).

Dalam kondisi normal saat seseorang melakukan pekerjaan sehari-hari, gelombang otak yang dominan adalah beta. Saat seseorang dalam keadaan relaks dan mulai terhipnosis, gelombang otak yang dominan mulai bergeser dari beta ke alpha (trans ringan). Trans merupakan kondisi ketika pikiran sadar seseorang tidak lagi memegang kendali seutuhnya dan mulai digantikan oleh pikiran bawah sadar. Semakin dalam orang masuk 
kedalam ke kondisi hipnosis, semakin rendah gelombang otaknya, mulai masuk ke theta (medium trance) dan bahkan sampai kepada gelombang delta (high trance), dimana seseorang tidur lelap tanpa mimpi.

Sugesti yang diberikan kepada seseorang secara berulang-ulang akan masuk ke dalam otak kanan (bawah sadar) dan akan melekat secara permanen. Sugesti yang masuk ke dalam pikiran bawah sadar sejak kecil perlahan-lahan akan menjadi sebuah kebiasaan hidup. Kebiasaan sejak kecil inilah yang telah menghipnosis pikiran seseorang. Menurut sebuah penelitian, hal-hal yang dilakukan atau didengar berulang-ulang selama 21 kali sangat berpotensi menjadi kebiasaan yang permanen.

Hipnosis merupakan suatu tahapan dimana seorang penghipnosis dapat membimbing suyet secara perlahan-lahan berpindah dari gelombang otak Betha ke Alpha dan pada kondisi tertentu dapam mencapai gelombang Theta. Untuk dapat dihipnotis seseorang harus mau (tidak menolak), memahani komunikasi, dan memiliki kemampuan untuk fokus. Secara alamiah terdapat tiga kelompok suyet, yaitu mereka yang mudah menerima hipnotis (10\%), yang moderat (85\%), dan yang sulit (5\%). (Iis Holiah, 2010: 80)

Lebih jauh Dylan Morgan (2011: 10) menjelaskan, dimana kita menyelidiki beberapa fakta dasar tentang cara yang ditempuh oleh otak dan tubuh bekerja secara spesifik kita melihat bagaimana kata-kata dan imajinasi dapat mengaktifkan system lain di dalam otak yangmana berhubungan dengan perasaan, otot, akal sehat, rasa keseimbangan dan lain-lain.

Sementara itu siapapun bisa jadi penghipnosis atau juru hipnosis dengan syarat memiliki kemampuan komunikasi verbal yang baik, memiliki rasa percaya diri yang tinggi, menguasai ilmu hipnosis dengan baik dan benar, selalu praktek, memiliki kemauan yang kuat (GNCH, 2008).

Berikut ini adalah tahapan-tahapan dalam proses hipnosis menurut Willy Wonk (2010:47), yaitu:

a. Pre-induction: Proses meyakinkan calon suyet untuk mau dihipnosis.

b. Induction: Proses membawa suyet ke dalam kondisi hipnosis.

c. Deepening : Proses untuk memperdalam level kesadaran seseorang. Makin dalam kondisi trance seseorang, maka makin mudah menerima berbagai macam sugersti, 
termasuk sugesti yang tidak masuk akal

d. Depth Level Test: Tes atau pengamatan dan kedalaman "trance" dari suyet.

e. Suggestion:Pemberian sugesti pada saat suyet sudah dalam kondisi "trance"/ tidur hipnosis.

f. Termination: Tahapan pengakhiran Subyek dikembalikan ke kondisi normal g. Post Hypnotic: Kondisi Suyet setelah termination

Pelaksanaan hypnoteaching harus diarahkan pada tujuan-tujuan positif yang membangun, yakni dengan memasukan kesan-kesan positif di alam bawah sadar siswa. Akan tetapi, dalam melaksanakan hypnoteaching, seorang guru harus berpenampilan rapih dan penuh percaya diri, sehingga memiliki daya tarik tersendiri. Selain sebagai pengajar dan pendidik, seorang guru harus mempunyai rasa empati dan simpati kepada para siswa. Jika guru memilki rasa simpati kepada siswa, niscaya siswa pun akan mempunyai rasa simpati kepada guru. Selain itu, guru perlu menggunakan tutur kata yang baik dengan memilih kosakata yang enak didengar oleh siswanya.

\section{METODOLOGI}

Metode penelitian ini menggunakan jenis penelitian deskriptif kualitatif. Seperti yang diungkapkan oleh Mardalis (2002:7) bahwa penelitian deskriptif bertujuan untuk mendeskripsikan apa-apa yang saat ini berlaku di dalamnya terdapat upaya mendeskripsikan, mencatat analisis dan menginterpretasikan kondisi-kondisi yang sekarang terjadi atau ada. Dengan kata lain penelitian deskripsi bertujuan memperoleh informasi-informasi mengenai keadaan saat ini, tidak menguji hipotesa atau tidak menggunakan hipotesa melainkan hanya mendeskripsikan informasi apa adanya sesuai dengan variabel-variabel yang diteliti.

Sedangkan penelitian kualitatif menurut Bogdan dan Tailor seperti yang dikutip Lexy J. Moleong (1999:3) yaitu sebagai prosedur penelitian yang menghasilkan data deskripsi berupa kata-kata tertulis atau lisan dari orang-orang dan perilaku yang diamati. Penelitian ini sepenuhnya berdasarkan riset lapangan yang dimaksudkan agar dapat melukiskan kondisi objektif keadaan tersebut. Dalam hal ini yang diteliti adalah implementasi teknik hypnoteaching dalam proses pembelajaran pada anak usia dini di sekolah. 
Sumber data adalah unsur utama dalam penelitian. Karena melalui sumber data ini, data-data konkrit dapat diperoleh dan dapat memberikan informasi untuk keperluan penelitian (Masri Singarimbun dan Sopian Effendi, 1999:122). Data ini ada yang primer dan sekunder. Data primer dapat diperoleh dari hasil observasi dan wawancara pribadi dengan pihak terkait, sedangkan data sekunder dapat diperoleh dari buku-buku, majalah, internet, jurnal dan sumber-sumber lainnya yang terkait dengan penelitian. Dan di dalamnya peneliti akan menggunakan pendekatan kualitatif yaitu membahas serta menganalisa kemudian menyimpulkan sebagai kesimpulan final apabila sudah memenuhi pertimbangannya.

Penelitian ini dilakukan di RA Dewi Sartika 3 Jagara Desa Darma Kabupaten Kuningan. Alasan menetapkan di lembaga ini sebagai sasaran penelitian adalah untuk melihat beberapa karakter yang berbeda dilihat dari usia anak, pengalaman anak dan latar belakang keluarga anak. Kategori pemilihan tempat di kabupaten Kuningan selain lokasi yang mudah di jangkau juga strategis, sehingga peneliti tidak mengalami kesulitan dalam menghimpun data dan informasi yang dibutuhkan.

Subjek penelitian adalah peneliti yang terlibat langsung dibantu oleh guru-guru yang ada di sekolah itu untuk menjadi mediasi dalam mengimplementasikan teknik hypoteaching di sekolah. Sedangkan objek penelitiannya adalah seluruh siswa di RA Dewi Sartika 3 Jagara Darma Kabupaten Kuningan.

Teknik pengumpulan data dalam penelitian ini, menggunakan teknik pengumpulan data sebagai berikut:

a. Observasi yaitu pengamatan dan pencatatan dengan sistematis fenomena-fenomena yang diselidiki (Sutrisno Hadi, 1984:141). Terkait dengan masalah bagaimana implementasi teknik hypnoteaching dalam proses pembelajaran pada anak usia dini di sekolah.

b. Interview (wawancara), yaitu percakapan dengan maksud tertentu. Wawancara ini dilakukan secara mendalam dan terstruktur. Susunan pertanyaan dan kata-kata dalam setiap pertanyaan dapat diperjelas pada saat wawancara berlangsung, disesuaikan dengan kebutuhan dan kondisi lapangan (Masri Singarimbun dan Sopian Effendi, 1999:61). Peneliti melakukan wawancara kepada guru, juga kepada siswa sebagai 
objek penelitian. Pelaksanaannya bisa melibatkan orang tua untuk menanyakan keluhan dan masalah yang dihadapi anaknya. Wawancara ini bertujuan untuk memperoleh data dan informasi sebelum peneliti menyusun pertanyaan terlebih dahulu yang berkaitan dengan objek peneliti sebagai pedoman wawancara yang dijadikan acuan pada saat wawancara berlangsung dengan siswa.

c. Dokumentasi, yaitu untuk mendapatkan data-data yang diperoleh dalam penelitian ini, dan untuk memperkuat hasil penelitian. Dalam hal ini diperoleh dari buku-buku, majalah, internet, jurnal dan sumber-sumber lainnya yang terkait dengan penelitian.

Teknik analisa data adalah suatu proses mengorganisasikan dan mengurutkan data ke dalam pola dan kategori tertentu. Selanjutnya data itu di analisa secara deskriptif agar mendapatkan hasil yang objektif (Lexy J. Moleong (1999:103). Tujuannya untuk menggambarkan pelaksanaan penggunaan teknik hypnoteaching dalam proses pembelajaran pada anak usia dini. Setelah data-data terkumpul maka langkah-langkah selanjutnya adalah analisa data yang diperoleh melalui pendekatan deskriptif kualitatif. Dalam hal ini data yang diperoleh akan di analisis dengan teknik analisa deskriptif yaitu peneliti menganalisa dan mendeskripsikan dalam bentuk pemaparan dengan memberikan penjelasan-penjelasan atau keterangan-keterangan secara logis.

Penelitian kualitatif ini menghasilkan transkip wawancara, catatan lapangan, gambar, tipe rekaman dan lain sebagainya (Kristi Purwandani, 1999:22).

\section{HASIL DAN PEMBAHASAN}

Pada penelitian kualitatif peneliti dituntut dapat menggali data berdasarkan apa yang diucapkan, dirasakan, dan dilakukan oleh sumber data. Pada penelitian kualitatif peneliti bukan sebagaimana seharusnya apa yang dipikirkan oleh peneliti tetapi berdasarkan sebagaimana adanya yang terjadi di lapangan, yang dialami, dirasakan, dan dipikirkan oleh sumber data.

\section{1) Implementasi teknik hypnoteaching dalam proses pembelajaran pada anak usia dini}

Pendidikan anak usia dini (PAUD) adalah jenjang pendidikan sebelum jenjang pendidikan dasar yang merupakan suatu upaya pembinaan yang ditujukan bagi anak usia 0 tahun sampai dengan usia enam tahun yang dilakukan melalui pemberian 
rangsangan pendidikan untuk membantu pertumbuhan dan perkembangan jasmani dan rohani agar anak memiliki kesiapan dalam memasuki pendidikan lebih lanjut, yang diselenggarakan pada jalur formal, nonformal, dan informal.

Pentingnya perkembangan anak usia dini bukan hanya diukur dan di kembangkan dari pengetahuannya saja tetapi dari emosi anak, bagaimana ia berinteraksi dengan masyarakat, bagaimana moral serta agama dan juga bagaimana perkembangan motorik halus dan kasar seorang anak. Kita semua pasti pernah mengikuti tes IQ, tahukah anda bahwa tes ini hanya mengukur satu kecerdasan tertentu, yaitu mengukur kecerdasan rasional, logis,dan linier jenis kecerdasan yang di pakai untuk problem logika tertentu dan untuk melakukan pemikiran strategis. Pada tahun 1960-an para ahli psikologi menemukan bahwa kelompok etnis dan gender yang berbeda bisa memperoleh skor tes IQ yang berbeda beda dan tidak menentu. Kesimpulan dari penelitian ini adalah bahwa kelompk etnis dan gender yang berbeda punya level kecerdasan yang berbeda.

Hypnoteching adalah suatu metode pembelajaran yang menggunakan teknik hypnosis, yang di maksud di sini adalah bahwa bagaimana anak di kondisikan dalam keadaan fokus pada kelas, guru dan juga pembelajaran. Hypnoteaching adalah salah satu pengembangan metode pembelajaran terbaru. Meskipun di Indonesia belum banyak yang menggunakan, tetapi hypnoteaching telah terbukti efektif dalam mengoptimalkan kegiatan belajar mengajar di sekolah. Dengan munculnya metode hypnoteaching, diharapkan masalahmasalah siswa yang terkait dengan pembelajaran di sekolah mampu dipecahkan. Secara tidak langsung, hal tersebut menuntut guru disekolah bisa menguasai hypnoteaching, karena hanya bisa dilakukan oleh seorang guru di sekolah.

Pelaksanaan hypnoteaching diarahkan pada tujuan-tujuan positif yang membangun, yakni dengan memasukan kesan-kesan positif di alam bawah sadar siswa. Akan tetapi, dalam melaksanakan hypnoteaching, seorang guru harus berpenampilan rapih dan penuh percaya diri, sehingga memiliki daya tarik tersendiri. Selain sebagai pengajar dan pendidik, seorang guru harus mempunyai rasa empati dan simpati kepada para siswa. Jika guru memilki rasa simpati kepada siswa, niscaya siswa pun akan mempunyai rasa simpati 
kepada guru. Selain itu, guru perlu menggunakan tutur kata yang baik dengan memilih kosakata yang enak didengar oleh siswanya.

Dalam hypnoteaching, sebagaimana yang terjadi pada hipnosis pada umumnya, penyajian materi pelajarannya menggunakan bahasa-bahasa bawah sadar yang menimbulkan sugesti siswa untuk berkonsentrasi secara penuh pada ilmu yang disampaikan oleh guru. Intinya hypnoteaching lebih banyak mengambil peranan pikiran bawah sadar. Frekuensi gelombang otak yang dipakai adalah alpha dan theta yang akan memproduksi hormon serotonin dan endrofin. Otak akan mengeluarkan hormon melatonin, catecholamine, dan arginine-vasopressin yang menyebabkan seseorang akan merasa nyaman, pikiranya sangat hening dan khusyuk, hatinya merasa tenang, serta bahagia dalam hidupnya. Inilah salah satu manfaat dati hypnoteaching.

Dalam mengimplementasikan hypnoteaching pada pembelajaran, maka haruslah menggunakan bahasa-bahasa bawah sadar. Hal ini dikarenakan agar perhatian siswa tersedot secara penuh terhadap materi yang disampaikan. Dengan begitu, siswa akan senantiasa memperhatikan, bahkan tidak akan berpaling pada hal-hal di luar pembelajaran.

Dalam melakukan hypnoteaching, hanya diperlukan langkah-langkah sederhana. Berikut ini adalah langkah-langkah dasar yang wajib dilakukan agar guru mampu menerapkan hypnoteaching.

a. Niat dan Motivasi dalam Diri Sendiri

Kesuksesan seseorang tergantung pada niat dalam dirinya untuk bersusah payah dan bekerja keras dalam mencapai kesuksesan tersebut. Sebab, niat yang besar akan memunculkan motivasi yang tinggi dan komitmen untuk konsen dan melayani apada bidang yang ditekuni.

\section{b. Pacing}

Pacing berarti menyamakan posisi, gerak tubuh, bahasa, serta gelombang otak dengan orang lain atau siswa. Sebab, pada prinsipnya manusia cendrung atau lebih suka berinteraksi dengan teman yang memiliki banyak kesamaan, sehingga ia akan merasa nyaman. Dengan kenyamanan yang bersumber dari kesamaan gelombang otak inilah, maka setiap pesan yang disampaikan dari satu orang ke orang lain bisa diterima dan dipahami dengan baik. 
Hal tersebut juga berlaku dalam penerapan pembelajaran hypnoteaching. Maksudnya, jika para siswa membenci pelajaran yang diberikan oleh guru, berarti gelombang otak guru belum setara dengan mereka. Meskipun usianya lebih tua daripada mereka, namun gelombang otak sebenarnya dapat disetarakan dengan seakanakan melakukan atau berfikir seperti mereka.

Adapun beberapa cara dalam melakukan pacing terhadap siswa dalam kegiatan belajar mengajar adalah sebagai berikut:

1. Bayangkan usia kita setara dengan siswa-siswa, sehingga kita dapat melakukan aktivitas dan merasakan hal-hal yang dialami oleh siswa saat ini, bukan saat kita masih sekolah dulu.

2. Gunakan bahasa sesuai dengan bahasa bahasa yang sering digunakan oleh siswa. Jika perlu, gunakan bahasa gaul yang sedang tren di kalangan siswa.

3. Lakukan gerakan-gerakan dan mimik wajah yang sesuai dengan tema bahasan.

4. Sangkutkan tema pelajaran dengan tema yang sedang tren di kalangan siswa.

5. Selalu update pengetahuan tentang tema, bahasa, hingga gossip terbaru yang sedang tren dikalangan siswa.

Dengan melakukan hal-hal tersebut, maka tanpa sadar gelombang pikiran guru telah sama dengan para siswanya, sehingga mereka merasa nyaman untuk bertemu gurunya. Jika hal ini terjadi, maka lanjutkan langlah berikutnya.

\section{c. Leading}

Leading memiliki pengertian memimpin atau mengarahkan sesuatu. Hal ini dilakukan setelah pacing dilakukan. Jika guru melakukan leading tanpa didahului dengan pacing, maka hal itu sama saja dengan memberikan perintah kepada para siswa yang cukup berisiko, karena mereka melakukanya dengan terpaksa dan tertekan. Hal ini akan berakibat pada penolakan mereka kepada guru.

Setelah melakukan pacing, para siswa akan merasa nyaman dengan gurunya. Pada saat itulah hampir setiap apa pun yang guru ucapkan atau tugaskan kepada mereka, akan dilakukan dengan suka rela dan bahagia. Sehingga, sesulit apapun materinya, pikiran bawah sadar mereka akan menangkap materi pelajaran dengan mudah. Mereka juga tidak akan merasa kesulitan dalam mengerjakan soal ujian, meskipun soal itu sulit.

\section{d. Gunakan Kata Positif}


Langkah keempat adalah langkah pendukung dalam melakukan pacing dan leading. Penggunaan kata positif ini sesuai dengan cara kerja pikiran bawah sadar yang tidak mau menerima kata negatif.

Pada dasarya, kata-ata yang diberikan oleh guru, baik langsung maupun tidak, sangat mempengaruhi kondisi psikis para siswa, sehingga mereka lebih percaya diri dalam menerima materi yang diberikan. Kata-kata tersebut dapat berupa ajakan dan himbauan. Jadi, apabila ada hal-hal yang tidak boleh dilakukan oleh mereka, hendaknya memakai kata ganti yang positif untuk mengganti kata-kata negatif. Sebagai contoh, apabila akan menenangkan kelas yang ramai, biasanya kata perintah yang keluar adalah, “Jangan rama!” Dalam mengaplikasikan hypnoteaching, hendaknya kata-kata jangan ramai ini diganti dengan, "Mohon tenang."

\section{e. Berikan Pujian}

Salah satu hal yang paling penting dalam pembelajaran adalah reward and punishment. Pujian meruapakan reward atas peningkatan harga diri seseorang. Pujian merupakan salah satu cara untuk membentuk konsep diri seseorang. Maka dari itu, berikanlah pujian kepada para siswa dengan tulus, sehingga mereka akan terdorong untuk melakukan yang lebih dari sebelumnya.

Pemberian pujian bisa dilakukan ketika siswa berhasil melakukan atau mencapai prestasi. Berikanlah pujian sekecil apapun bentuk prestasinya, termasuk ketika ia berhasil melakukan perubahan positif pada dirinya sendiri. Meskipun mungkin masih di bawah temantemanya, tetaplah berikan pujian.

Dalam memberikan pujian, hindari pula kata penghubung negative, misalnya "tapi", "namun" dan lain sebagainya. Penggunaan kata-kata tersebut akan membuat pujian sia-sia dan terkesan mengolok-olok. Jika pujian digabungkan dengan kritk atau saran, maka yang lebih tertangkap adalah bentuk penyerangan pada diri orang yang dipuji, hal ini justru akan menjatuhkanya. Meskipun tampaknya merupakan hal sepele dan sering terjadi, namun efeknya sangat besar dalam system psikologinya.

f. Modeling

Modeling adalah proses memberi teladan atau contoh melalui ucapan dan perilaku yang konsisten dan merupakan salah satu kunci keberhasilan dalam hypnoteaching. Setelah 
para siswa merasa nyaman dengan guru, maka ia perlu memantapkan perilakunya agar konsisten dengan ucapan dan ajaranya, sehingga ia selalu menjadi figur yang dipercaya.

Penelitian yang dilakukan terdiri dari satu kali observasi dan 3 kali memberikan perlakuan. Perlakuan dalan penelitian ini menggunakan metode hypnoteaching dan di dalam metode ini ada tahap pemberian sugesti, sugesti yang diberikan haruslah bersifat positif dan tidak ada kata negative. Adapun sugesti yang diberikan guru pada anak adalah:

1. Ketika kita merasa senang baiknya kita bersyukur dan mengucapkan kata kata yang baik.

2. Ketika kita merasa sedih boleh menangis dan ceritakanlah pada orang tua atau guru.

3. Ketika kita sedang marah bicaralah baik-baik kepada orang lain mengapa kita marah.

4. Ketika kita merasa takut maka bicaralah pada orang yang lebih dewasa tentang ketakutan kita.

5. Ketika kita melakukan kesalahan yang sengaja maupun tidak sengaja kita harus meminta maaf kepada orang tersebut

6. Ketika menunggu giliran kita harus tertib menunggu dengan sabar

7. Ketika teman melakukan salah kepada kita maafkanlah teman kita

8. Masalah itu harus di selesaikan dengan tenang.

9. Tugas yang diberikan oleh guru dan orang tua harus di selesaikan dengan senang hati.

10. Ketika kita mengerjakan tugas kerjakanlah sendiri.

11. Ketik kita melihat karya orang lain pujilah dengan kata-kata yang baik dan menyenangkan.

12. Berteman dengan siapa saja, karena semua teman sama saja.

13. Ketika ada yang berbicara dengarkanlah

14. Ketika kita sedang bermain bersama harus saling berbagi mainan dengan teman dan tentu saja kembalikan bila mainan itu bukan punya kita.

15. Ketika kita ingin meminta atau meminjam berbicaralah yang baik pada teman

Dari hasil tersebut maka akan dibahas lebih jelas melalui deskripsi berikut: Guru mengambil data sesuai yang tertera pada lembar observasi. Pengambilan data dimulai 
pada pukul 07.00 - 07.30 pada saat guru menyambut anak dan bersalaman dengan para guru. Pada pukul 07.30- 08.00 kegiatan dimulai dengan berbaris bersama semua kelas di depan sekolah lalu masuk bergantian ke dalam kelas masing masing. Pada 08.00-08.15 dilakukan apersepsi pembacaan asmaul husna berdoa sebelum belajar dan tanya jawab kegiatan kemarin dan bercakap cakap kegiatan hari ini. Kegiatan selanjutnya adalah kegiatan inti, kegiatan yang dilakukan adalah menempel, mewarnai dan menggunting benda benda langit kegiatan ini berakhir pada jam 09.00. kegiatan selanjutnya adalah kegiatan istirahat yaitu bermain di luar sampai 09.30, dilanjutkan makan bersama sampai jam 10.00 kegiatan selanjutnya adalah kegiatan outdoor yaitu persiapan untuk pentas seni akhir tahun ajaran semester genap sampai jam 10.30 .

Data yang di ambil pada saat pretest adalah data yang sesuai dengan indikator pada instrumen dengan cara mengobservasi anak mulai dari kegiatan penyambutan sampai kegiatan akhir dan pulang. Untuk indikator perasaan yang ditunjukan oleh anak pada hari itu seperti perasaan senang sedih marah dan takut dan juga bagaimana anak menjalin hubungan atau berteman dengan temannya peneliti mengamatinya dimulai dari awal pembelajaran sampai akhir pembelajaran, sedangkan untuk hal seperti motivasi dalam mengerjakan tugas penyelesaian dalam pengerjaan tugas peneliti mengamati pada saat kegiatan inti, dan untuk kegiatan mengantri peneliti mengamati pada saat anak mengantri untuk cuci tangan sebelum makan dan mengantri saat mau keluar untuk pembelajaran outdoor.

Treatment yang dilakukan peneliti dimulai dari awal pembelajaran hingga akhir pembelajaran dan posttest diambil pada saat kegiatan berlangsung. Treatment yang yang dilakukan guru adalah pembelajaran hypnoteaching dengan teknik hypnoteaching circle time method. Perlakuan dimulai pada pukul 07.00-07.30 guru menyambut siswa guru memberikan sambutan bahwa anak sangat ditunggu di sekolah unuk belajar, yang biasanya untuk penyambutan hanya ditanyakan kabar dan mengucapkan selamat pagi peneliti menambahkan seperti menanyakan perasaan memberikan semangat untuk belajar dan bertanya apakah anak siap untuk bermain bersama guru. Pada pukul 07.3008.00 kegiatan dimulai dengan membuat lingkaran lalu bernyanyi lagu dan kemudian masuk ke dalam kelas masing masing. 
Pada tahap awal tindakan, sebelum pembelajaran dimulai guru memperkenalkan dirinya terlebih dahulu kemudian dilanjutkan dengan perkenalan siswa. Hal ini dilakukan untuk menciptakan kedekatan secara mental kepada siswa, guru juga wajib menghafal semua nama siswa-siswanya.

Sebelum pembelajaran dimulai, terlebih dahulu guru merelaksasi (menenangkan) siswa-siswanya. Hal ini dilakukan untuk menurunkan gelombang otak siswa dari beta $(30-14 \mathrm{hz})$ ke alpha $(13,9-8 \mathrm{hz})$ atau theta $(7,9-4 \mathrm{hz})$. Ketika siswa berada pada gelombang otak alpha atau theta yang tenang, santai, dan nyaman. Maka pada saat itulah pikiran bawah sadar mulai terbuka dan pada saat gelombang otak alpha dan theta inilah guru memberikan sugesti-sugesti yang positif untuk kepentingan pembelajaranya.

Setelah guru membuat siswa tenang dan nyaman dengan teknik hypnosis ini. Langkah selanjutnya yang guru lakukan dalam hypnoteaching ini adalah membuat anchor (stimulus yang menimbulkan reaksi), seperti guru mengucapkan "Hello" maka murid menjawabnya dengan "Hai" begitupun sebaliknya. Anchor ini harus dibiasakan untuk menciptakan stimulus yang menimbulkan reaksi. Anchor ini sangat bermanfaat untuk untuk membuat siswa kembali fokus ke materi yang disampaikan oleh guru.

Pada saat masuk kelas guru melakukan tahap pre-talk atau pre-interview dan juga pengondisian siswa, siswa duduk dan membuat lingkaran dengan aturan duduk dengan posisi sila dan kakinya mengenai kaki temannya lalu memulai kegiatan dengan berdoa terlebih dahulu kemudian bercakap cakap tentang kegiatan apa yang akan kita lakukan hari ini dan bertanya kepada anak apakah anak siap untuk bermain bersama, ini dilakukan agar anak ada dalam kondisi relaks dan senang dalam belajar, ini termasuk dalam tahapan uji sugestibilitas dalam tahapan ini anak pun disuruh untuk saling berpegangan tangan dan menarik nafas dalam dalam dan dikeluarkan secara perlahan. Dalam tahap ini guru menemukan kendala yaitu pada saat dilakukan tahap ini sedikit terganggu karna suara suara dari kelas lain sedangkan seharusnya ketika melakukan hypnoteaching dibutuhkan suasana yang tenang dan kondusif. Maka yang dilakukan guru adalah pengalihan perhatian seperti sautan kepada anak agar anak tetap fokus kepada guru. 
Setelah dilakukannya pre-talk dan uji sugestibilitas dilanjutkan pada tahap induksi, tahap ini dimana guru melihat dan mengecek kembali apakah anakanak siap untuk melakukan pembelajaran, guru melakukannya dengan cara anak disuruh untuk menutup matanya bila anak telah fokus dan sudah terkondisikan maka anak akan mematuhi aturan, dalam tahap ini ada satu anak yaitu dia tidak dapat fokus dalam kondisi kelas karena dia ingin belajar di luar akhirnya guru mencoba membujuk dan memfokuskan kembali dia agar belajar dalam kelas. Sebelum ke tahap seanjutnya yaitu pemberian sugesti guru kembali mengkondisikan siswa dan mengecek kesiapan siswa yaitu dengan mengulangi perintah untuk menutup mata dalam tahap ini di sebut juga tahap deepening.

Selanjutnya guru melanjutkan pada tahap sugesti. Pertama guru bertanya tentang ekspresi senang sedih marah dan takut, kemudian diajukan pertanyaan pertanyaan berlanjut pada pemberian sugesti kepada anak sesuai dengan apa yang telah ditentukan oleh guru, dan sugesti di lakukan dengan kata-kata yang dapat di mengerti anak.

Setelah itu di lanjutkan dengan kegiatan inti disini. Anak di berikan kegiatan menggambar dan mewarnai tentang hujan dan matahari. Kegiatan selanjutnya adalah istirahat selama 30 menit setelah anak anak istirahat anak mengantri untuk mencuci tangan lalu makan bersama.

Kegiatan setelah makan bersama adalah kegiatan recalling disini guru menggunakan waktu ini untuk melakukan teknik terminator yaitu pengakhiran proses belajar mengajar menggunakan metode hypnoteaching yaitu dengan cara menanyakan kegiatan hari ini dan bertanya tentang perasaan anak. Maka demikianlah perlakuan yang diberikan oleh guru dalam pembelajaran berakhir. Selain melakukan perlakuan guru juga mengambil data post test pertama tentang hasil yang didapat setelah melakukan perlakuan terhadap anak.

Pada treatment yang kedua ini pelaksanaan penelitian pindah ke luar sekolah yaitu masjid karena untuk mengatasi masalah yang muncul pada treatment pertama. Adapun keadaan sarana dan prasarana di masjid tersebut cukup memadai masjid 
tersebut memiliki ruang kelas yang biasanya digunakan untuk Taman Pendidikan Alquran (TPA) pada sore hari, di masjid itu pun ada ayunan dan permainan outdoor lainnya.

Pada treatment yang ke 2 guru menggunakan metode hypnoteaching dengan teknik hypnoteaching playing method. Perlakuan yang diberikan sama seperti perlakuan sebelumnya dimulai pada pukul 07.00-07.30 guru menyambut siswa guru memberikan sambutan bahwa anak sangat ditunggu di sekolah unuk belajar, menanyakan perasaan memberikan semangat untuk belajar dan bertanya apakah anak siap untuk bermain bersama guru. Pada pukul 07.30-08.00 kegiatan dimulai dengan membuat lingkaran lalu bernyanyi lagu dan kemudian dilanjutkan dengan berjalan menuju masjid. Sambil jalan menuju masjid anak di ajak bernyanyi dengan guru.

Sesampainya di masjid anak di kondisikan untuk melepas dan menata sepatu masing masing dan kita melakukan pembelajaran di teras masjid. Setelah itu kita mulai pembelajaran dengan tahap awal yaitu pre-talk atau pre-interview dan juga pengondisian siswa, yang mana siswa duduk dan membuat lingkaran dengan aturan duduk dengan posisi sila dan kakinya mengenai kaki temannya lalu memulai kegiatan dengan berdoa terlebih dahulu kemudian di lanjut dengan bercakap-cakap tentang kegiatan apa yang akan kita lakukan hari ini dan bertanya kepada anak apakah anak siap untuk bermain bersama, untuk pengondisian ini guru melakukannya dengan memainkan sebuah permainan. Permainan ini dengan memberikan intruksi; angkat tangan kanan lalu letakan tangan kanan di kaki kanan di lanjutkan dengan mengangkat tangan kiri lalu letakan tangan kiri di atas tangan kanan teman samping kiri, dan dimulai lah permainan dengan bernyanyi dan menepuk tangan kanan teman yang ada di sebelah kiri permainan ini berhenti ketika lagunya habis.

Setelah melakukan permainan kita melanjutkan pada uji sugestibilitas tahap ini dilakukan agar anak kembali ada dalam kondisi relaks dan senang dalam belajar, dalam tahapan ini anak pun disuruh untuk saling berpegangan tangan dan menarik nafas dalam dalam dan dikeluarkan secara perlahan.

Setelah dilakukannya pre-talk dan uji sugestibilitas dilanjutkan pada tahap induksi, tahap ini dimana guru melihat dan mengecek kembali apakah anakanak siap untuk melakukan pembelajaran, guru kembali melakukannya dengan cara 
yang sama pada treatment 1 anak disuruh untuk menutup matanya bila anak telah fokus dan sudah terkondisikan anak akan mematuhi aturan, setelah menutup mata anak di ajak untuk menarik nafas panjang lalu dikeluarkan secara perlahan, dan diulang sebanyak 3 kali. Hal ini di ulang sampai 3 kali karena dalam kegiatan ini sudah masuk ke dalam tahap deepening yaitu tahap dimana pengondisian peserta didik benar-benar sudah ada dalam kondisi relaks dan kondusif untuk menerima sugesti.

Selanjutnya guru melanjutkan pada tahap sugesti yang dilakukan sama dengan pada treatment 1. pertama guru bertanya tentang ekspresi senang sedih marah. Setelah di ajukan pertanyaan pertanyaan berlanjut pada pemberian sugesti kepada anak sesuai dengan apa telah ditentukan oleh guru, dan sugesti di lakukan dengan kata kata yang dapat di mengerti anak.

Setelah itu di lanjutkan dengan kegiatan inti disini anak di berikan kegiatan kolase fenomena pelangi. Anak menempel kertas sesuai dengan warna-warna pelangi anak menempel pada gambar yang telah disediakan oleh guru. Setelah melakukan kegiatan inti anak di kondisikan untuk bersiap siap untuk makan anak diminta untuk mengantri cuci tangan dengan tertib setelah itu duduk melingkar dan makan bersama.

Kegiatan setelah makan bersama adalah kegiatan recalling disini guru menggunakan waktu ini untuk melakukan tahap terminator yaitu pengakhiran proses belajar mengajar menggunakan metode hypnoteaching yaitu dengan cara menanyakan kegiatan hari ini dan bertanya tentang perasaan anak. Setelah selesai pada kegiatan ini guru mengkondisikan peserta didik untuk kembali ke sekolah tetapi sebelumnya peserta didik diajak membereskan tempat yang telah dipakai bersama sama. Maka demikianlah perlakuan yang diberikan oleh guru dalam pembelajaran berakhir.

\section{2) Hambatan yang mempengaruhi pelaksanaan teknik hypnoteaching dalam proses pembelajaran di RA}

Hambatan pelaksanaan teknik hypnoteaching sering terjadi pada saat kegiatan observasi, pada awalnya siswa tampak belum terbiasa dengan yang namanya relaksasi (penenangan), maka pada saat relaksasi berlangsung masih ada beberapa siswa yang bercanda dan kurang melaksanakan tugas dari guru dengan baik, sehingga proses relaksasi 
untuk menurunkan frekuensi gelombang otak agar terbukanya pikiran bawah sadar kurang sempurna dilakukam, karena masih ada beberapa siswa yang bercanda.

Hambatan lainnya yang mempengaruhi pelaksanaan teknik hypnoteaching adalah tidak semua guru di PAUD kompeten dalam pelaksanaan hipnoteaching dan membutuhkan pelatihan-pelatihan. Faktor pendukung dari hipnoteaching harus ada kesediaan dari klien dan bukan paksaan dengan suasana yang mendukung dan adanya komunikasi. Faktor penghambatnya, karena tidak ada guru yang kompeten dalam menggunakan teknik ini maka harus mendatangkan ahli dan mahalnya biaya pelatihan.

Penghambat lancarnya pelaksanaan hipnoterapi yaitu kedua orangtuanya, ayah dan ibu, tidak bersedia bertemu terapis untuk menjalani sesi wawancara mendalam dan konseling. Syarat ini sangat penting untuk dipenuhi. Biasanya bila salah satu orangtua tidak bersedia atau berkenan hadir maka kami biasanya akan mempertimbangkan melakukan proses hipnoteaching pada anak mereka. Syarat ini tentu tidak berlaku bagi orangtua tunggal (single parent).

Dalam pelaksanaan teknik hypnoteaching guru menemukan kendala yaitu pada saat dilakukan tahap ini sering terganggu karena suara-suara dari kelas lain sedangkan seharusnya ketika melakukan hypnoteaching dibutuhkan suasana yang tenang dan kondusif. Maka yang dilakukan guru adalah pengalihan perhatian seperti sautan kepada anak agar anak tetap fokus kepada guru. Akan tetapi tetap saja anak-anak kurang fokus, maka membutuhkan kesabaran yang ekstra dalam menghadapi anak-anak usia dini.

\section{3) Dampak keberhasilan implementasi teknik hypnoteaching dalam proses pembelajaran di RA}

Dampak keberhasilan teknik hypnoteaching bagi anak tidak begitu memberikan kontribusi secara ideal, karena membutuhkan peran serta orang tua dalam prosesnya serta keterbatasan waktu yang diberikan pihak sekolah, akan tetapi melalui beberapa sesi yang diterapkan, dampaknya bagi klien banyak yang merasakan suatu perubahan yang signifikan. Masalah-masalah kilen yang menghambat proses pembelajaran seperti malas dalam belajar, susah untuk menghapal, minder, kurang percaya diri dan masalah-masalah psikhis lainnya alhamdulillah melalui teknik ini bisa teratasi kelihatan dari hasil evaluasi di kelas, walaupun 
tidak secara maksimal karena beberapa hambatan teknis dari pihak sekolah dan keterbatasan waktu yang diberikan kepada peneliti.

Perubahan-perubahan pada diri klien terlihat dari sifat dan perilakunya yang menunjukan keceriaan dan motivasi dalam belajarnya, sholat berjamaah (duha dan duhur) di sekolahpun rajin, bahkan klien/siswa menunjukan sikap dan karakter yang baik dalam kelas dan pergaulan dengan teman-temannya. Hal ini menunjukan bahwa penggunaan teknik ini memberikan kontribusi yang sangat signifikan terhadap pembentukan karakter siswa di sekolah.

Hasil wawancara dengan guru di PAUD, dia menjelaskan bahwa teknik hypnoteaching akan mampu mengubah karakter siswa dengan cara mengubah mindset siswa ketika siswa merasa minder dalam bergaul dan meningkatkan rasa kepercayaan diri dan enjoy dalam berinteraksi. Perilaku siswa anak usia dini di kelas yang kurang baik berubah menjadi baik setelah guru memberikan sugesti-sugesti positif dalam proses hipnosis. Kepatuhan siswa terhadap guru dan motaivasi belajar siswa meningkat setelah dilakukan pendekatan hipnosis selama pembelajaran.

\section{SIMPULAN}

Berdasarkan hasil penelitian yang penulis lakukan tentang "implementasi teknik hypnoteaching dalam proses pembelajaran pada anak usia dini”, maka dapat diambil kesimpulan sebagai berikut:

1. Hypnoteching merupakan suatu metode pembelajaran yang menggunakan teknik hypnosis, anak di kondisikan dalam keadaan fokus pada kelas, guru dan juga pembelajaran. Hypnoteaching adalah salah satu pengembangan metode pembelajaran terbaru dan telah terbukti efektif dalam mengoptimalkan kegiatan belajar mengajar di sekolah. Dengan munculnya metode hypnoteaching, diharapkan masalah-masalah siswa yang terkait dengan pembelajaran di sekolah mampu dipecahkan. Secara tidak langsung, hal tersebut menuntut guru di sekolah bisa menguasai hypnoteaching, karena hanya bisa dilakukan oleh seorang guru di sekolah.

2. Pelaksanaan hypnoteaching pada Anak Usia Dini harus diarahkan pada tujuan-tujuan positif yang membangun, yakni dengan memasukan kesan-kesan positif di alam bawah sadar siswa. Akan tetapi, dalam melaksanakan hypnoteaching, seorang guru 
harus berpenampilan rapih dan penuh percaya diri, sehingga memiliki daya tarik tersendiri. Selain sebagai pengajar dan pendidik, seorang guru harus mempunyai rasa empati dan simpati kepada para siswa. Jika guru memilki rasa simpati kepada siswa, niscaya siswa pun akan mempunyai rasa simpati kepada guru. Selain itu, guru perlu menggunakan tutur kata yang baik dengan memilih kosakata yang enak didengar oleh siswanya.

3. Walaupun banyak hambatan dalam mengimplementasikan teknik hypnoteaching, akan tetapi melalui beberapa sesi yang diterapkan, dampaknya bagi anak banyak yang merasakan suatu perubahan yang signifikan. Masalah-masalah anak yang menghambat proses pembelajaran dengan menggunakan teknik ini bisa teratasi kelihatan dari hasil evaluasi di kelas, walaupun tidak secara maksimal karena memerlukan waktu yang begitu inten. Perubahan-perubahan pada diri klien terlihat dari sifat dan perilakunya yang menunjukan keceriaan dan motivasi dalam belajarnya.

\section{DAFTAR PUSTAKA}

Almatin, Isma. 2010. Dahsyatnya Hypnosis Learning : Untuk Guru dan Orang Tua. Yogyakarta, Pustaka Widyatama.

Bachtiar, Wardi, 1999, Metodologi Penelitian Ilmu Dakwah, Jakarta: Logos

Departemen Pendidikan Nasional. 2008. Kamus Besar Bahasa Indonesia. Jakarta : Gramedia Pustaka Utama.

Fachri, Hisyam A. 2008. The Real Art of Hypnosis: Kolaborasi Seni Hypnosis Timur-Barat. Jakarta : Gagas Media.

GNCH. 2008. Apakah Hipnosis Itu?. Modul Pelatihan Hipnosis. Bandung : NHC.

Hadi, Sutrisno, 1984, Metodologi Penelitian Research II, Jakarta: Puspa Swara.

Hajar, Ibnu. 2011. Hypnoteaching : Memaksimalkan Hasil Proses Belajar Mengajar dengan Hipnoterapi. Yogyakarta: DIVA Press.

Holiah, Iis. 2010. Pendekatan Hypnoteaching Sebagai Sebuah Inovasi Dalam Pembelajaran. (makalah lomba guru teladan tingkat nasional).

Mardalis, 2002, Metode Penelitian Suatu Pendekatan Proposal, Jakarta: Bumi Aksara.

Moleong, Lexy J., 1999, Metode Penelitian Kualitatif, Bandung: Remaja Rosdakarya 
Morgan, Dylan. 2011. Hypnosis for Beginners (Hipnotis untuk pemula). Yogyakarta: Lahar Publisher.

Noer, Muhammad. 2010. Hypnoteaching For Succes Learning. Yogyakarta: PT Pustaka Insan Madani.

Nugroho. 2008. Transformasi Diri, Memberdayakan Diri melalui Hipnoterapi. Jakarta : Gramedia.

Pertiwi, Hana, 2014, Hypno-teaching untuk PAID dan TK, Jogjakarta: Diva Press

Surya, Mohammad. 2004. Psikologi Pembelajaran dan Pengajaran. Bandung: Pustaka Bani Quraisy.

Sangarimbun, Masri \& Effendi Sofian, 1999, Metode Penelitian Survey, Jakarta: LP3ES.

Sogiyanto. 2006. Filosofi Pendekatan, dan Penerapan Pembelajaran Metode Kasus. Yogyakarta : Andi Offset.

Sudjana, Nana, 2002, Dasar-dasar Proses Belajar Mengajar, Bandung: Sinar Baru Al Gensindo

Wonk, Willy. dan Andri Hakim. 2010. Dahsyatnya Hipnosis. Jakarta : Visi Media. 